\title{
As órfãs d'el-Rei: Racialized Sex and the Politicization of Life in Manuel da Nóbrega's Letters from Brazil
}

OLIMPIA E. ROSENTHAL

Indiana University Bloomington

\begin{abstract}
Between 1551 and 1608/1609, five groups of Portuguese female orphans were sent to Brazil as part the Crown's efforts to populate the colony. The first group arrived in response to Father Manuel da Nóbrega's initial petition and, as this practice developed into policy, his views were decisive in the conceptualization of this project. Through an analysis of Nóbrega's letters, this essay traces the central presuppositions on which this colonial project was based, and theorizes its implications. It highlights the institutional mechanisms that made possible and helped shape this global traffic in women and argues that this specific case evinces an early and stark politicization of life.
\end{abstract}

Keywords: biopolitics; gender; colonial Brazil; reproduction; race

In a letter dated January 6, 1550, Father Manuel da Nóbrega, writing from Porto Seguro (Brazil), makes the following petition to the Provincial of the Portuguese Jesuits, Father Simão Rodrigues: “Se El-Rei determina povoar mais esta terra, é necessário que venham muitas mulheres órfãs e de toda a qualidade até meretrizes, porque há aqui varias qualidades de homens; e os bons e os ricos casarão com as órfãs; e deste modo se evitarão pecados e aumentará a população no serviço de Deus" (Cartas do Brasil 79-80). As the passage indicates, Nóbrega's request is first and foremost tied to the question of populating the colony. He articulates his appeal for orphaned women from Portugal as a response to the king's presumed determination to populate, and he authorizes his views by situating his locus of enunciation in the very colony where said 
population is at stake. The emphasis on the quantity of women justifies Nóbrega's suggestion that even prostitutes are acceptable, and it adds a sense of urgency to his tone. It also speaks to the social vulnerability of the particular type of women that he targets in his request: orphans and prostitutes. In addition to specifying that these women would aid in the reproduction of a specific social group, what he refers to as the segment of the population at the service of God, Nóbrega alludes to the sins that could be prevented by having the orphans marry the colonists. Though in this letter he does not state of what these sins might consist, Nóbrega had previously written about the widespread occurrence of extra-marital polygamous relations between Portuguese men and Amerindian women. This practice alarmed him not only because simple fornication was considered a sin, but because the colonists who adopted these local sexual customs insisted that what they were doing was not a $\sin .{ }^{1}$ It is this type of permissive sexual interactions between the colonists and Amerindian women that Nóbrega sought to curtail by requesting that Portuguese women-irrespective of their virtuousness - be sent to Brazil. It is clear, then, that his petition is organized around a dual objective. On the one hand, it is presented as a plan to help expand the Christian population in the colony. His appeal is expressed as being consistent with the colonial imperative to populate, and it is founded on the assumption that women's biological role in reproduction can be made instrumental to such an endeavor. On the other hand, Nóbrega's proposal claims to offer a partial solution to the sinful sexual practices taking place in the colony. His perceived need for women is premised on a dismissal of Amerindian women as worthy marriage partners, and it introduces a marked gender distinction that becomes progressively racialized as his views on the matter develop.

In 1551, not long after Nóbrega's unusual request, the first group of Portuguese women arrived in Brazil. It was a small group, comprised of three orphaned sisters. Soon afterward, Nóbrega again petitioned that Portuguese

\footnotetext{
${ }^{1}$ As Stuart B. Schwartz explains about the Americas: "the inculcation of sin as a personal concern became a principal objective of the missionaries" ("Sin" 321). He further traces the notion of simple fornication arguing that towards the middle of the sixteenth century the Inquisition intensified its efforts to modify popular beliefs over the ambivalence of whether or not simple fornication was considered a sin ("Pecar en colonias" 54). In Nóbrega's case, the question of inculcating sin appears as a central concern, and is often directly tied to his request for Portuguese orphans.
} 
women be sent to the colony in a missive dated September 14, 1551, and then once more at the beginning of July 1552. In subsequent years, there were four additional groups of female orphans who arrived in Brazil. Indeed, by the second half of the sixteenth century, the practice of sending orphans to the colonies had developed into a much broader policy that included destinations in India and Africa. In addition, it was a policy facilitated by some of Portugal's most eminent institutions.

Nóbrega's early correspondence stands at the juncture between the initial discursive articulation of this project and the many vicissitudes of its implementation. By offering a historically-contextualized reading of Nóbrega's letters, I examine the central presuppositions on which this colonial project was based and theorize its implications. I begin by discussing what is known regarding the órfãs d'el-Rei that went to Brazil, and I highlight the institutional mechanisms that made possible, and helped shape, this global traffic in women. I further argue that this project evinces a politicization of life that is at once founded on an instrumentalized view of women's role in reproduction, and that is premised on a prior racialized distinction of women structured around the problematization of racialized sex. My analysis of this colonial project sheds light on the historical articulations of race, sex, and reproduction, and it helps justify a temporal reconfiguration of Michel Foucault's notion of biopower by building from Ann L. Stoler's critique that his work systematically bypasses crucial colonial discourses on racialized sex. Finally, it contributes to current scholarship on processes of racialization in colonial Latin America. ${ }^{2}$

\footnotetext{
${ }^{2}$ The term racialized sexuality was first coined by Abdul JanMohamed to describe the shortcomings of Foucault's theory of sexuality insofar as these fail to articulate clearly the points of intersection between the deployment of sexuality and the deployment of race (94). JanMohamed defines racialized sexuality as "the point where the deployment of sexuality intersects with the deployment of race" (94). Throughout this essay, I use the term "racialized sex" rather than "racialized sexuality" as a way to elude controversies over the periodization of the term "sexuality." By "racialized sex," I mean sexual relations that are deemed problematic because of an underlying racial distinction that becomes reified precisely when the idea of a sexual/racial divide is thought to have been transgressed through sex. For JanMohamed, the idea of a racial divide is always already a sexual border, and it is the transgression of this socio-juridically constructed border that characterizes what he defines as racialized sexuality (JanMohamed 104, 109). Similarly, Joane Nagel argues that racial boundaries are also sexual boundaries that are, at once, transgressed by erotic crossings, but also patrolled, policed, and protected $(107,113)$.
} 


\section{As órfãs d'el-Rei}

The fragments of information that we have about the female orphans sent to Brazil come from limited primary sources consisting mainly of notary and Inquisition records. Historiographical accounts are likewise scant; however, together these sources offer important glimpses into the lives of these women. Though their exact number is unknown, extant data suggest that fewer than thirty women ultimately arrived in Brazil. ${ }^{3}$ To date, Rodolfo García's 1946 study continues to be the most comprehensive account of the five groups of orphans that arrived between 1551 and 1608/1609. He provides the names for fourteen of these women, mentions six others who are referenced in documents but who remain unidentified, and pieces together brief descriptions of what is known of their lives in the colony. Since one of García's main goals is to trace the genealogy of some of Brazil's oldest and most noble families to these women, the majority of the information that he provides focuses on the orphans' marriages and their descendants. His account offers little in the way of interpretive insight, but he does include a passing explanation of Nóbrega's request for women. As García puts it: "É fato natural nas sociedades em formação, como era a do Brasil por meiados do primeiro século, a falta de mulheres; entenda-se, no caso de mulheres brancas, porque daqcelas [sic] da terra, das chamadas índias . . havia sobras, e delas usaram e abusaram os colonos" (137). He continues by stating that "as brancas disponíveis eram raras," and he recounts an incident, described by Nóbrega, when several colonists fought over a Portuguese nursemaid who had recently arrived with the Armada (137). It is this incident, according to García, that prompted Nóbrega to write his petition for Portuguese orphans. García's assertion, that it is a natural fact that all emergent societies are characterized by a scarcity of women, assumes, as he acknowledges, that Amerindian women are excluded from his particular vision

\footnotetext{
${ }^{3}$ The relatively low number of orphans that went to Brazil needs to be contextualized, given that the total number of colonists was likewise quite limited. Although demographic records for this period are sparse, Justin R. Bucifferro's review of existing scholarship suggests that by 1550 there were at most three to four thousand European settlers across all captaincies in Brazil, with only about three hundred estimated to have been in Bahia (290). According to Maria Luiza Marcílio, the overall number of European settlers across all captaincies increased to about 20,000 by 1570 and 30,000 by 1580 (45).
} 
of Brazil's nascent colonial society. He admits that Portuguese men "used and abused" indigenous women (recognizing euphemistically European desire for them), but he clearly specifies that the terms of these sexual relations were casual, temporary, and exploitative. In other words, he implies that these were not the type of relations upon which a new society should wish to be founded. The reproductive consequences of these unions are left unconsidered by García, even though they are central to Nóbrega's argument. According to García's interpretation, it was the colonists' natural predilection for Portuguese women that best explains this project's formation.

Consulting primary sources related to the órfas d'el-Rei, one is confronted by a different set of limitations, and it is not always a more effective way to further our understanding of this project and its implications. It is striking that, for two out of the five known groups of orphans that went to Brazil, the existing documents available generate more questions than they answer. Two sources in particular epitomize the type of narrative silences that confront scholars working on this topic. The first of these is the Instrumento dos serviços de Mem de Sá from September 1570. It recounts Mem de Sá's services to the Crown during his years as the third governor-general of Brazil, and it begins by explaining what happened when he first departed from Lisbon in 1557 along with his crew and the six female orphans that João III had ordered him to take with him. According to his account, bad weather threw his company's ships off course, and it was not until eight months later that they finally reached Brazil. Mem de Sá declares that during this period he lost 42 out of the 330 men who had left Lisbon with him. He points out, though, that all six orphans made it safely to their destination. While the significant loss of life is indicative of the perils passengers faced on the journey, Mem de Sá states that he diligently provided the women with the necessary sustenance for them to endure the long trip. He goes on to add that once in Brazil he labored to secure their marriages (Biblioteca Nacional, Anais 27:130). What is most conspicuous about the depositions given in corroboration of Mem de Sá's account, however, is the consistency with which all of the men testifying - with the notable exception of Bishop Dom Pero Leitão-narrate what happened to the orphans. In almost identical terms, eleven of the twelve men testifying state that the orphans were well provided for during the voyage and each of them emphasize that once they arrived in Brazil, Mem de Sá ensured that all women married "honradamente" (Biblioteca Nacional, Anais 27:137-210). 
Few of them offer any additional information, and all of them use the exact same terminology. The formulaic nature of these types of notarial documents is not enough to explain away the impeccably consistent retelling of events that had occurred almost thirteen years earlier. The Bishop's refusal to comment when asked about this specific matter, moreover, draws attention to the case, and it raises questions about his unwillingness to confirm the otherwise uniform narrative - especially given his position as a moral authority. This silence is made more prominent by the fact that the orphans' perspective remains unaccounted for in the official record. In a similar vein, a sense of historical inaccessibility typifies the single existing source on the last-known group of orphans that disembarked in Brazil sometime between 1608 and 1609. The sole record that attests to their arrival specifies neither the number of women nor their identity. It is a letter dated February 8, 1609 and addressed to Felipe III that closes with a paragraph stating that the captain and the pilot of the ship transporting the orphans, Sebastião Martins and his brother, have been arrested and sent back to Portugal to be judged for the abuses they perpetrated against the orphans:

Nesta carauela mando Sebastião Martinz preso e entregue ao mestre della que se chama Antonio Luis o qual mando se entregue no Conselho e a quem o Presidente mandar o porque vai preso he pella deuassa que delle e seu irmão mestre e piloto da sua carauela os quais trouverão as orfãs e lhe aconteceo no caminho o que consta pella deuassa que já tenho mandado à $\mathrm{V}$. Magestade. (Ministério da Educação, Anais 57:50)

The wording is extremely vague, making it impossible to ascertain with any level of certainty what type of abuses the women may have suffered on their journey to Brazil. García obliquely suggests that the orphans were most likely sexually assaulted (143). The sense of dealing with but a fragmentary history of these women's lives is perhaps nowhere more acutely felt than upon reading the brief description of the Martins brothers' arrest. As Stoler suggests in reference to archival sources, the impoverished testimony that characterizes regimes of official documentation produces the experts who in turn can only partially (re)produce written traces of colonial lives (Along the Archival Grain 19).

The most complete set of information that we have about the orphans that went to Brazil is in studies that have looked at the function of dowries that helped 
facilitate this global traffic in women. Imperial dowries were awarded by the institutions that housed and eventually shipped the orphans overseas, and these consisted mainly of state offices granted to the prospective husbands. As Timothy Coates explains, the practice of sending orphaned women to the colonies formed part of a broader strategy for colonization designed to meet Portugal's empire-building needs. The ultimate goal of this strategy was to populate distant colonies and, for this, the Portuguese Crown adopted a dual model of forced and state-sponsored colonization. On the one hand, the Portuguese state punished its criminals and sinners by sending them off as convicted exiles (degredados) to the colonies. Such a tactic operated as a means of internal social control, and it provided the needed manpower for colonizing (Coates xiii). The payment of dowries, on the other hand, functioned as an alternative approach to colonization, as Coates argues:

Imperial dowries were a solution to several issues: rewarding past services to the Crown; protecting daughters orphaned by such service; attending to pressing social needs at home in the form of an increasing number of such needy women; and stabilizing the colonial presence of a Portuguese elite, either born in the European homeland or directly descended from those who were. (3)

What this means is that the Portuguese state rewarded orphaned women with dowries and sponsored their voyage overseas as an integral part of a broader colonial strategy.

In the case of the first group of sisters that arrived in Brazil in 1551, we see precisely the implementation of such colonial logic. Catarina, Joana, and Micia were the orphaned daughters of Baltasar Lobo de Sousa, a man who had lost his life as a member of the Portuguese armada while working to secure imperial trade routes from Lisbon to Goa (Jaboatão 77). The dowries granted to his daughters were a way to reward his service to the Crown posthumously, by ensuring the respective marriages and financial security of his daughters. The three sisters also arrived in Brazil with orders from João III that they were to marry "pessoas principais da terra" (qtd. in García 138). Though Catarina did not marry (in spite of a special 1555 provision that increased the prestige of the colonial post that would be granted to her husband as part of her dowry), her two sisters did. Joana, 
however, had to go to great lengths to maintain the social status she achieved when, as part of her dowry, her husband Rodrigo de Argolo was awarded the position as provedor da fazenda in the city of Salvador (García 138). The socioeconomic stability that accompanied this post was soon jeopardized by Rodrigo's failing health and, upon his death, Joana was forced to arrange a marriage between their eldest daughter (who at the time could not have been more than six years old) and a much older man. As García explains, given the fact that the girl was prepubescent and did not bear children for another decade, the reason for the marriage was clearly the husband's desire for the dowry (139). As this case demonstrates, the provision of imperial dowries was a tenuous strategy to establish a socio-economic link between the colony and the metropole, and one in which unmarried women served as the nexus. According to Coates, despite the multiple problems that arose, dowries nonetheless helped institute what can aptly be described as a "marriage scheme" between colonial authorities and metropolitan institutions (144).

To be awarded an imperial dowry was considered an honor, and it carried with it coveted social and material benefits. The institutions that granted these dowries and eventually sent the orphans overseas are themselves an important source of information for understanding some of the imperial values that the órfas d'el-Rei were expected to uphold. The Casa da Misericórdia was one of the main institutions responsible for establishing orphanages in Portugal and for providing the orphans with dowries (Coates 16). The most important orphanage that the Casa helped establish in Lisbon was the Recolhimento do Castelo, which required proof of blood purity for admission (Almeida 185). This meant that women of Jewish, Muslim, or mulatto background were barred from entering. ${ }^{4}$ Though there were exceptions to this rule - as in the case of Catharina Frois, who arrived in Brazil as part of the third group of orphans, and who testified to the Inquisition in 1591 that she was the daughter of an Old Christian father and a New Christian mother (Abreu 53) - the concern with blood purity was a

\footnotetext{
${ }^{4}$ As Hebe Mattos explains, the category mulato began to be included in Portuguese blood purity regulations at the beginning of the seventeenth century (43). According to Mattos, in Portugal and especially in Brazil, the formulation "sem raça de mouro, judeo ou mulato" became a common phrase in countless documents (50). This indicates that, as notions of blood purity developed, skin color became an important marker of im/purity.
} 
consistent feature associated with these institutions. ${ }^{5}$ These restrictions reflect the institutional influence that blood purity statutes had gained in Portugal after the establishment of the Inquisition in 1536, and it speaks to the type of imperial values that informed the selection criteria for the órfas d'el-Rei. Most orphanages also stipulated that the orphans be between the age of twelve and forty, that they be neither ill nor have any physical defects, and that they be required to take a vow of chastity as part of the admission process (Coates 130; Guedes 666). Moreover, as Suely Creusa Cordeiro de Almeida has shown, the series of disciplinary measures inside these institutions subjected the women to tight controls over their bodies (183). Contact with people from the exterior was prohibited, they were only allowed to read certain texts (such as marriage manuals that delineated the qualities of a perfect marriage and indicated the traditional gender roles that women should perform when married), and they were often subjected to physical punishment for failing to adhere to the orphanage's rules (Almeida 182-83). Coates also recounts an incident in which two women were punished for having "uma amizade de mã suspeita," indicating that same-sex desire was likewise carefully supervised (131). The mission of these institutions was thus to inscribe women's bodies with imperial values that could then be presented as exemplary for other women in the colonies.

Before proceeding, it is important to reflect on the circulation of women that constitutes the very basis for the orfãs project. In her analysis of traffic in women and what she terms the political economy of sex, Gayle Rubin argues that the exchange of women between men can be an analytically powerful concept in that it places the oppression of women within social systems, rather than in biology. Drawing on Claude Lévi-Strauss's work on kinship, she describes marriages as the most basic form of gift exchange, in which women are the most precious of gifts (Rubin 43). The kinship systems that are formed through the exchange of women between men are understood by Rubin, following Lévi-Strauss, as an imposition of cultural organization upon the facts of biological procreation (42). Though Rubin acknowledges that the exchange of women does not necessarily

\footnotetext{
${ }^{5}$ Although Frois admitted that she was "mea cristão velha," she was not summoned by the Inquisition for this reason. Her testimony before the Inquisition's first visit to Brazil (1591-92) instead emerged from charges that she had paid a feiticeira to ensure the death or disappearance of her abusive son-in-law, then fighting in Sergipe (53).
} 
imply that women are objectified in the modern sense, the central problem that she identifies is that, as gifts rather than exchange partners, "women are in no position to realize the benefits of their own circulation. As long as the relations specify that men exchange women, it is men who are the beneficiaries of the product of such exchanges - social organization" (44-45). Rubin admits that men are of course also trafficked, most notably as slaves, but never just as men. Women, on the other hand, as she says, "are transacted as slaves, serfs, and prostitutes, but also simply as women" (Rubin 45). As an analytical framework, Rubin's assertions can help us to think about the órfas d'el-Rei. To begin with, this case can easily be read as an example of women being transacted as women. The very title used to describe the orphans clearly invokes the paternal protection of no less a figure than the king, and it implies that the orphans were under his symbolic and material protection. As Coates suggests, these were not just any orphan girls - the title used to describe them made this clear (143). The official posts that were granted as dowries to the colonists who would marry the orphans served as enticing incentives, and they provided the central mechanism through which to organize this global traffic in women. As a strategy to meet the Crown's imperial needs, this marriage scheme was also an effective means to achieve colonial social organization. The obvious problem, of course, is that as cases such as Joana's make clear, the women themselves were only in an indirect position to access the benefits of their own circulation.

It is also important to note that the question of reproduction was central to orfãs project (Guedes 665). By facilitating the circulation of orphans and other socially vulnerable women to the colonies, the Portuguese Crown was seeking more than simply to promote church-sanctioned marriages. Its hope was to intervene in and direct the very reproduction of the colonial population (Guedes 665). The particular social organization that emerged through this exchange in women thus implied a direct imposition of politics upon the facts of biological procreation. It is on the question of reproduction, however, that a major analytical limitation emerges in Rubin's conceptualization. As important as her insights are for framing some of the implications of this project in terms of feminist critique, her theory ultimately rests on an overly essentialized notion of gender that ultimately limits its utility for the case of the orphans. As a deeper analysis of Nóbrega's letters demonstrates, it is not enough to think of this project only in terms of women being traded as women. Rather, it is necessary to take into 
account that the orfãs were limited to Old Christian women with no African ancestry.

The second issue that must be addressed in order to begin delineating some of the implications of this case study is race. Though there is still controversy regarding the validity of race as a category of analysis for the early modern period, numerous scholars have recently revisited Iberian notions of blood purity precisely to help dispel this skepticism (Sussman, Bethencourt, Martínez, and Fredrickson). The work of María Elena Martínez has been particularly influential in this regard. First of all, Martínez challenges the claim that it is anachronistic to think about the concept of race prior to its articulation by nineteenth-century science. As she puts it, "arguing that racial discourses took a particular form in the nineteenth century is one thing; contending that they did not operate in the early modern period, quite another" (11). For Martínez, the point is not to argue that there is a single, transhistorical form of racism but rather to contribute to our understanding of the historical trajectory of race, paying particular attention to its social and historical conditions of possibility, and to its articulations with sex and gender. Martínez's account of the rise of blood purity statutes in Iberia is especially relevant for the present analysis for two very precise reasons. In the first place, her work demonstrates that notions of blood purity were never limited to Iberia; they journeyed to the Americas, where they decisively influenced, and were influenced by, colonial processes of racialization (Martínez 1). Also, her careful examination of the critical shift that blood purity statutes inaugurated brings to light what these statutes meant for ideas regarding intermarriage and the feminization of impurity (Martínez 54-58). As Martínez's work, and that of others, has shown, following the forced conversions of Jews and Muslims in Spain and Portugal, blood purity statutes were instituted in order to differentiate nominally and socially between Iberians of "pure" Old Christian ancestry and socalled New Christians or conversos. In the process of doing so, the role of genealogy became a fundamental factor in determining a person's religious and socio-cultural identity. David Nirenberg describes this transition as a "genealogical turn," arguing that forms of identity that had previously been legal and religious were replaced by essentialized, genealogical categories (75). According to Martínez, this "newly invigorated concern with lineage was rooted in the idea that 'Jewishness' was transmitted in the blood, that it was a natural, inheritable condition" (28). The conflation of culture and biology that shapes 
these views was, as Martínez explains, derived from both religious texts and from the main physiological theories of the Middle Ages, which - heavily influenced by Ancient Greek science and medicine - tended to accord semen, breast milk, blood, and food an integral role in the creation and function of life (47-48). A central feature of this genealogical turn, then, was the belief that biological inheritance had a deterministic influence in shaping a person's character, one that even conversion (sincere or otherwise) could not help to overcome. Max S. Hering Torres contends that this shift further expanded the meaning of impurity to the body and, like Martínez, he maintains that anxieties over the possible transmission of hereditary impurities led to heightened concerns that breast milk from Muslim or converso wet nurses could contaminate Old Christian children (Hering Torres 19, Martínez 56). These ideas also confirmed for officials the dangers of intermarriage and intersexual relations codified in blood purity statutes and led to a heightened association of women with impurity (Nirenberg 75, Martínez 55). It is within the context of these critical transformations that some of broader implications of the órfas d'el-Rei must be considered. As noted earlier, notions of blood purity were central tenets of the institutions that facilitated this global trade in women, and they clearly influenced its overall imperial design. It remains to be seen, however, how Nóbrega's petition for orphans articulates racialized distinctions, and how this informs the politicization of life that is at the heart of this colonial project.

\section{Racialized Sex and the Politicization of Life}

In the first two decades after the Portuguese first landed in Brazil in April 1500, their presence on the Brazilian coast remained occasional and intermittent (Schwartz, Early Brazil 13). It was not until the 1520s, under the governance of João III, that new strategies for colonizing were more actively implemented. As Carlos Alberto de Moura Ribeiro Zeron points out, during this time Diogo Gouveia played an important role in shaping the course of this history as an influential adviser to the king (46). Gouveia's letters show that he believed that a permanent occupation of Brazil was the best defense against the frequent incursions of foreign powers into the territory; furthermore, they make explicit the fact that, from his point of view, populating the land was necessary to achieve this end (Zeron 46). Gouveia insisted repeatedly that sending Portuguese settlers 
to Brazil would help to quickly reproduce that population and, in a letter to João III from 1532, he mentions that marriages between the Portuguese and the indigenous could likewise contribute to the efforts of populating the colony (Zeron 47). Zeron argues that João III fully adopted Gouveia's suggestions and offers as evidence a letter from the Portuguese king to Martim Afonso de Sousa on the occasion of the latter's 1532 expedition to ensure Portugal's control of the territory. In it, João III tells Sousa that it would be a great service to "povoar-se toda esta costa do Brasil" (qtd. in Zeron 47). This emphasis on stimulating population growth as part of a political strategy for coloniziation is suggestive of some of the shifts that begin taking shape during this period, and it points to some of the ways in which the fostering of life begins to be increasingly politicized. Given that for Foucault the critical shift that characterizes the beginning of biopower is precisely the fact that power over life begins to express itself less in the form of an ancient sovereign right and more in the mechanisms that foster the birth and life of individuals and populations (The History of Sexuality 138), we begin to see here the traces of what in Nóbrega's petition for Portuguese women becomes an even more overt politicization of life.

Between 1532 and 1549, the captaincy system put in place by João III consisted of dividing the Brazilian coast into fifteen hereditary captaincies assigned to twelve men who, in turn, assumed the responsibility of protecting, settling, and developing their respective territorial grants (Zeron 49, Schwartz, Early Brazil 13). After the eventual failure of this system, however, the Crown finally set out to establish a more direct form of control over the colony. ${ }^{6}$ Nóbrega's arrival in Brazil, on March 29, 1549, coincides exactly with the beginning of a new colonial tactic adopted by the Crown. In 1549, João III

\footnotetext{
${ }^{6}$ As Alida C. Metcalf explains, "For thirty years after the discovery of Brazil, from 15001530, the Portuguese saw Brazil as simply another entrepôt, similar to the many trading posts along the coast of Africa where Portuguese ships stopped on the way to and from India to trade for slaves. At the few trading posts in Brazil, the Portuguese traded with the local Indian tribes or the pau brasil. ... Each of the trading posts had a factor and a small garrison of soldiers to protect it" (27-28). In this sense, the early years of Brazilian colonization were similar to the system of feitorias established in Africa. João III's efforts to populate Brazil, however, point to a significant difference to the system of feitorias that begins taking shape with the captaincy system, and a clear break with it is marked by the appointment of Tomé de Sousa as the new governor-general of Brazil in 1549.
} 
appointed Tomé de Sousa as the new governor-general of Brazil and gave him express orders to "instill order and to effect some means by which men may more safely and effectively go over there to populate the territory" (Schwartz, Early Brazil 37). The move implied an administrative centralization of power in Bahia, and it entailed the transfer of metropolitan bureaucratic systems to the colony (Zeron 55). The expedition that accompanied Tomé de Sousa also reveals the political reorientation that was beginning to take place. It included the largest armed force up to that point, numerous colonists (most of which were not penal exiles), civil and military functionaries and, notably, the first Jesuit mission under the command of Nóbrega (Zeron 56, Leite, Breve itinerário 52). While Nóbrega's main mission in Brazil was to inaugurate a more systematic approach to the religious conversion of the natives, as part of the more general effort to establish a permanent Portuguese settlement, his writings indicate that he soon became fixated on the regularization of the colonists' marriage practices, an issue that, for him, was inextricably tied to the need to promote that population's legitimate reproduction.

In the very first letter that Nóbrega wrote from Brazil, dated April 10, 1549, he specifies that at the time of their arrival in Vila Velha, there were only some forty to fifty Portuguese colonists (Cartas do Brasil 18). Speaking about these colonists, he comments that: "a gente da terra vive toda em peccado mortal, e nom há nehum que deixe de ter muytas negras das quaes estão cheos de filhos, e hé grande mal" (Cartas do Brasil 19). ${ }^{7}$ The fact that the colonists lived in polygamous relations with Amerindian women is characterized by Nóbrega as a mortal sin, proscribing explicitly any type of identification of this scene with the type of edenic innocence described in Pêro Vaz de Caminha's canonical account of the discovery. ${ }^{8}$ Nóbrega's emphasis on the sinful nature of these relations, which he says involve all colonists, is only offset by his statement that the multiple children that are the result of these sexual unions are equally

\footnotetext{
${ }^{7}$ Vila Velha was subsequently re-founded as Salvador da Bahia. Though there is some ambiguity in the wording of this passage, Serafim Leite clarifies in an accompanying footnote that when Nóbrega refers here to "gente da terra" he is indeed referring to the Portuguese colonists.

${ }^{8}$ As Rogério Miguel Puga suggests, Caminha's letter, written in 1500 and describing the first Portuguese contact with Brazil, includes a series of descriptions of Amerindian women's naked bodies characterized by a sense of edenic purity and innocence that often overtakes the Catholic observer (78).
} 
problematic. The fact that Nóbrega refers to indigenous women as negras, moreover, is telling of the type of exploitative conditions in which these relations were embedded. As Stuart Schwartz explains, the expression negras da terra was commonly used by Jesuits and other colonists to refer to indigenous slaves. The phrase was used as a parallel to the expression negros da Guiné and it implied that that the adjective "negro" had become a synonym for slave ("Indian Labor" 61). Schwartz maintains that the use of this expression indicates that the hierarchical categories of social definition that were already operative in Portugal - especially those that resulted from Portuguese explorations in Africa-were reactivated in the Brazilian colony in relation to Amerindians ("Indian Labor" 61). Though Nóbrega himself spoke out against indigenous slavery on a number of occasions - mainly on the grounds that in their expeditions to acquire these slaves the Portuguese used incorrect methods and provided Amerindians with a bad example of Christian ethics - it is clear from the passage above that he also deployed commonplace labels for social differentiation that were clearly based on assumptions about skin color having a bearing on a person's social condition (Zeron 71). ${ }^{9}$ What is most striking about Nóbrega's articulation of the perceived problem, however, is the fact that sex becomes an issue not only because of the polygamous extra-marital relations that he mentions, but, more importantly, because skin color is introduced as the mark for the socially differentiated groups that this act brings together. It is precisely by racializing the perceived dangers of these sexual relations that the very notion of racial differences gets reified. In other words, it is the perceived transgression of the idea of a racial/sexual divide that then retroactively confirms the fact that socio-racial differentiation was already operative in his conception of the perceived problem. Considering that Nóbrega's description of Amerindians as negros is also tied to his assertion that the Portuguese who cohabitate and bear children with them is a "grande mal," his comment further suggests that skin color was in no way superfluous to his negative perception of the newly emerging colonial population. This is particularly significant in light of Hering Torres's

\footnotetext{
${ }^{9}$ Nóbrega was in fact involved in the first meeting convoked in 1556 by Mem de Sá to discuss the question of indigenous slavery in Brazil. The meeting featured the debate between Nóbrega and Quirio Caxas, a professor from the Colegio da Bahía (Eisenberg 9, 12). For an analysis of this debate see Eisenberg.
} 
argument that, in the context of the Americas, notions of blood purity were soon linked to skin color, as notions of impurity were progressively associated with the body (24).

As Nóbrega's preoccupation with the regularization of the colonists' sexual and marriage practices deepened, the idea of importing Portuguese women to the colony gradually begins to appear in his letters as a possible solution. In a letter from August 1549, speaking again about the great sins of the colonists who have taken on the local custom of polygamous, extra-marital sex, he writes:

Todos se me escusam que não têm mulheres com que casem, e conheço eu que casariam si achassem com quem; em tanto que uma mulher, ama de um homem casado que veiu nesta armada, pelejavam sobre ella a quem a haveria por mulher. ... Parece-me cousa mui conveniente mandar Sua Alteza algumas mulheres que lá têm pouco remedio de casamento a estas partes, ainda que fossem erradas, porque casarão todas mui bem.... De maneira que logo as mulheres terão remedio de vida, e estes homens remediariam suas almas, e facilmente se povoaria a terra. (Cartas Jesuiticas 79-80)

The rhetorical persuasiveness of the passage is organized around an incident that is meant to typify just how desired Portuguese women are in the colony. Nóbrega endorses the colonists' supposed claim that they are not marrying simply because there are no worthy marriage partners in the colony. In this sense, he shifts from blaming them for their sinful unions with Amerindian women to identifying a broader social situation in which he timidly suggests the Crown should intervene. The stated convenience of sending socially vulnerable Portuguese women to the colony is also founded on the assumption that even "morally questionable" women - that is, "mulheres que lá têm pouco remedio de casamento"-would be welcomed and well received as marriage partners by the colonists. Nóbrega thus presents the manifest hierarchy between Amerindian and Portuguese women as something that goes beyond a mere question of virtue; rather, it speaks to the particular policy of population growth to which Nóbrega's recommendation appeals. His assertion that the colony could be easily populated by sending Portuguese women implies not only a politicization of life, but a politicization of life predicated on the disqualification of indigenous women. 
Appealing to Foucault's conceptualization of biopower to think about the politicization of life that is central to this colonial project is both analytically useful and theoretically justified. To begin with, the theory of biopower provides a methodical account of the historical articulations of race, sex, and reproduction. According to Foucault, a critical shift in the mechanisms of power over life begins to take shape in the seventeenth century and reaches its full constitutive force by the nineteenth century. In The History of Sexuality, Foucault summarizes this shift by suggesting that "the ancient [sovereign] right to take life or let live was replaced by a power to foster life or disallow it to the point of death" (138). Foucault argues that biopower encompasses both disciplinary technologies centered on the individual body - what he terms "an anatomo-politics of the human body" - and regulatory controls aimed at the population as a whole, which he terms "a biopolitics of a population" (The History of Sexuality 139). As Stoler explains, what makes biopower unique is precisely the fact that it "joins two distinct technologies of power operating at different levels" (Race and the Education of Desire 33). Foucault theorizes the interconnections between race and sexuality by suggesting that they both emerge alongside biopower and, like it, operate on the level of the individual and the population. More specifically, as Ladelle McWorther argues, the central intersection between race and sex that Foucault identifies emerges when major goals for populations are concerned (54). Foucault maintains that sexuality, being an eminently corporeal mode of behavior, is a matter for individualizing disciplinary controls that take the form of permanent surveillance. Yet, because sexuality has procreative effects as well, it is also inscribed in broad biological processes that concern not the bodies of individuals, but rather the perceived unity of the population (Foucault, "Society Must Be Defended" 251-52). Like sexuality, Foucault contends that racism involves both disciplinary controls aimed at producing docile bodies, as well as regulatory mechanisms targeting the population as a whole. Foucault theorizes racism's relation to the power over life almost exclusively in terms of death, arguing for instance that "[o]nce the State functions in the biopower mode, racism alone can justify the murderous function of the State" ("Society Must Be Defended" 256); however, as Paul Rabinow and Nikolas Rose point out, while exceptional forms of biopower can indeed lead to a type of thanatopolitics, its characteristic function entails a relation between "letting die" and "making live," that is to say, strategies for the governing, not taking, of life (195). The 
undertheorized quality of some of Foucault's insights on this matter seem to typify the kind of conceptual deadlocks that he was encountering in his theorization of race, and it is precisely such gaps that justify going beyond the temporal delimitations of his work.

Giorgio Agamben's reformulation of the notion of biopower is productive insofar as it questions the chronological specificity of Foucault's conceptualization. As Leland de la Durantaye explains:

The initial modification that Agamben effects to Foucault's historical schema is to show that the 'biopower' Foucault saw as most distinctive of the modern age - as the most distinctively modern thing about our political life and the specific forms that state power now takes-is actually as old as Western politics itself. It is therefore not an effect, as Foucault had claimed, of the shift from a sovereign to a disciplinary society. (210)

There are, however, two major limitations to Agamben's work, specifically for thinking about the órfãs d'el-Rei. On the one hand, as Michael Dillon contends, the key point of disagreement between Agamben and Foucault is that while for Agamben the question of biopower is ultimately one of ontology, for Foucault it is one of historicization (42). The type of ahistoricity to which Agamben's conceptualization can lead is of little analytical value for tracing the type of biopolitical shift that this essay argues is evinced in the case of the orphans. On the other hand, Agamben's evasion of the question of race is likewise a theoretical hindrance to thinking about some of the major implications of the colonial project in question. As Judith Butler argues, Abamben's general claims about bare life do little to explain how power functions differentially to target and manage certain populations on the basis of ethnicity and race (68). While his conceptualization of biopolitics is still important for questioning the historical parameters and circumscription of the question of sovereignty in Foucault's theory, Agamben's work is less compelling for framing the type of arguments developed here. In contrast, Stoler's work offers a much more pertinent historical, and ultimately geographical, displacement of Foucault's theory of biopower. 
Stoler argues that Foucault systematically bypasses crucial colonial discourses on racialized sex. By doing so, Stoler maintains, his analysis of how biopower was deployed during the eighteenth and nineteenth centuries around the issues of sexuality and race overlooks a key site: the colonial context. Stoler's intention is not to question the validity of Foucault's assertions, but rather she seeks to demonstrate how, by reconfiguring Foucault's chronology and displacing his focus to the colonies, we can engage in a more profound inquiry into the historical articulations of race and sex. Though her work emphasizes the fact that sex was an issue that was repeatedly discussed between metropolitan administrative apparatuses and the colonists-specifically since sex was regularly linked to the potentialities of colonial settlement and to the production of populations that would be made loyal to emerging colonial states - she admits that these were not discourses of sexuality comparable to those of the eighteenth and nineteenth centuries studied by Foucault (Race and the Education of Desire 40). She rightly insists, however, "that the discursive management of sexual practices of colonizer and colonized was fundamental to the colonial order of things" (Race and the Education of Desire 4). One of Stoler's most significant contributions is her contention that "an implicit racial grammar underwrote the sexual regimes of bourgeois culture in more ways than Foucault explored" (Race and the Education of Desire 12). She discusses in detail the development of Foucault's views on race but, as she points out, it is clear that after 1977 Foucault abandoned his investigations on race altogether; a close associate of his has suggested that he was "deadlocked on thinking about race" (qtd. in Stoler, Race and the Education of Desire 25). By bringing these issues to the fore, and suggesting that it is up to colonial scholars to use his work and go beyond it, Stoler's work urges us to re-conceptualize the historical delimitations of Foucault's theory.

Returning to Nóbrega's concerns over polygamy and legitimate reproduction in colonial Brazil, one notes an increasing sense of urgency. After less than a year in Brazil, he would write his first official petition for the arrival of Portuguese women to the colony. Though the question of skin color is not present in relation to the women he requests in his first missive, this issue becomes progressively more pronounced in subsequent letters. In his letter from 1551, Nóbrega writes: 
Pera as outras Capitanias mande V.A. molheres órfãs, porque todas casarão. Nesta nam são necessárias por agora por averem muitas filhas de homeins brancos e índias da terra, as quais todas agora casarão com a ajuda do Senhor; e se nam casavam dantes, era porque consentiam viver os homens em seus peccados livremente, e por isto nam se curavão tanto de casar e alguns deziam que não pecavão. (Cartas do Brasil 102; emphasis my own)

In this case, Nóbrega begins by requesting that female orphans be sent to some of the newer colonial settlements in the region. As he says, in the village of Olinda (from which he writes), women are no longer in such dire need considering the high number of mestiças there. His careful wording in this passage emphasizes that these women are the daughters of white men and indias da terra, thus highlighting the fact that the latter are not enslaved. Furthermore, he stresses that the mestiças that are helping alleviate the alleged shortage of women in Olinda are no longer consenting to live with men outside of marriage; they have instead adopted the Portuguese practice of monogamous churchsanctioned marriage. This point is highly significant considering Nóbrega's skeptical views about mestiços vis-à-vis the Portuguese. In a letter from 1556, speaking about the indigenous custom that permitted sexual unions between uncles and nieces - which Nóbrega strictly condemns as being against papal bulls and canon law, as well as contrary to the "impedimento de consanguinidade" (Cartas do Brasil 206) - he states that on this issue "[os] mestiços da terra ... são iguais com o gentio" (Cartas do Brasil 206). Similarly, in a letter from 1561 addressed to Diego Laynez, Nóbrega concludes by asking whether recent marriage stipulations will be applicable to the descendants of Christian mestiços since, as he adds "alguns deles são tais, que deles aos mesmos gentios há pouca diferença" (Cartas do Brasil 394). It is unclear to which specific marriage reforms Nóbrega is referring; however, in the copy of his letter found in Rome, a side note indicates that the same marriage rules do apply to mestiços (Cartas do Brasil 394). As each of these letters indicate, Nóbrega remained doubtful that mestiços - even the descendants of Christian mestiços - could indeed be considered equal to the Portuguese. As he repeatedly states, in many ways they continued to be almost the same as Amerindians, as if something about their genealogical heritage carried with it a type of impurity that even conversion to Christianity could not expunge. In this sense, Nóbrega appears to be endorsing 
notions of blood purity, even if he reconfigures them within the context of emerging colonial processes of racialization. This anxiety over the socially ambiguous position of mestiços, moreover, was for Nóbrega crucially tied to marriage, and hence to legitimate reproduction. Though this characterization of mestiços as neither quite Portuguese nor quite Amerindian continued to be a preoccupation, it is significant that in the letter cited above he was willing to accept certain mestiça women as legitimate marriage partners for the colonists. As the letter suggests, however, this did not minimize the need for white Christian women in the colony.

In his final letter petitioning for orphans (1552), Nóbrega explicitly specifies the skin color of the women he requests. Addressed directly to João III, he writes:

Já que escrevi a V. A. ha falta que nesta terra há de molheres com que os homens casem e vivão em serviço de N. Senhor apartados dos peccados em que agora vivem, mande V.A. muitas orfãas e, se não houver muitas, venhão de mestura dellas, e quaisquer porque são tão desejadas as molheres brancas quá, que quaisquer farão quá muito bem à terra, e ellas se ganharão e os homens de quá apartar-se-ão do pecado. (Nóbrega Cartas do Brasil 114, emphasis my own)

Although the question of sin is present in all of Nóbrega's letters on the transfer of women, in this case he specifically states that by sending white women to the colony, Portuguese men will distance themselves from the sins in which they currently live. These sins, as I have already mentioned, are not merely an issue of polygamy and extra-marital sexual relations. Their conceptualization is further intertwined with a hierarchical gender distinction that privileges Portuguese over Amerindian women as ideal marriage partners for the colonists. While it is true that Nóbrega also makes hierarchical distinctions between Portuguese womenfor instance when he distinguishes between prostitutes, other wrongdoers, and the orphans - the passage above makes clear that, despite the differences among them, the common attribute that makes their presence in the colony so desirable is, as he overtly states, their whiteness. The purifying effects that he ascribes to the presence of white women are thus directly correlated to his implicit portrayal of Amerindian women as enablers of sin. What this indicates, then, is that his petition for women is racially coded, in the sense that the central problem with 
sexual relations that he identifies is premised on a racialized distinction between women. This is not to minimize the cultural importance of Portuguese women in the colonies; as Charles Boxer has argued, in many of the settlements that had few or no Portuguese women, the metropolitan language, religion, and culture were severely diluted (35). As John R. Russell-Wood suggests, however, white women were also seen as "[an] instrument for populating the vast expanses of Portuguese America" (33). From this point of view, the role of white women in the colony expands beyond the realm of culture as women's reproductive capacity becomes intertwined with the colonial imperative to populate.

Nóbrega's petition for female orphans is thus part of a broader trend in which the fostering of life begins to be increasingly politicized as part of a colonizing strategy. Coates has presented the practice of sending orphan women to the colonies as a colonial strategy designed to populate and give shape to distant colonies. An examination of João III's policies in Brazil confirms this reading. There is a critical difference, however, between Gouveia's initial suggestion to the Crown that marriages between the Portuguese and the indigenous were a valid means to stimulate population growth and the inauguration of global traffic in Portuguese women to the colonies. In the latter case, there are two significant changes that Nóbrega's letters requesting orphans help us trace. First, it is clear that women's biological role in reproduction is rendered instrumental to the colonial imperative to populate. The institutions in Portugal that facilitated the orphans' transportation to the colonies instilled in them the value of churchsanctioned marriages, it offered the colonists enticing incentives to marry them, and, most importantly, is sought to encourage procreation through these unions. It also becomes clear from Nóbrega's letters that race is an important factor in the specific politicization of life that is at the heart of this colonial project. White Christian women were sent to the colony because the specific form of population growth that was sought was premised on the disqualification of indigenous women. The portrayal of Amerindian women in Nóbrega's letters suggests that he associated them not only with extra-marital sex but also with sin and impurity - both issues that were in turn intertwined with ideas regarding skin color. The politicization of life that is at the center of this project thus pivots around a policy that endorses endogamous sex as a means of fostering the life of a particular segment of the population while framing miscegenation as the root of the problem for which a corrective was sought in the first place. The case of 
the orfãs d'el-Rei thus presents us with the irreducible interrelations between race, sex, and biopower. The case of the orphans offers important insights into these interrelations and highlights the utility of raising these questions from within the colonial order of things.

\section{Works Cited}

Abreu, J. Capistrano de, ed. Primeira Visitação do Santo Oficio às partes do Brasil: Confissões da Bahia 1591-92. Rio de Janeiro: Briguiet, 1935. Print.

Almeida, Suely Creusa Cordeiro de. $O$ sexo devoto: normatização e resistência feminina no Império Português XVI-XVIII. Recife: UFRPE, 2005. Print.

Biblioteca Nacional do Brasil. Annaes da Biblioteca Nacional do Rio de Janeiro, vol. 27. Rio de Janeiro: Biblioteca Nacional, 1906. Print.

Bethencourt, Francisco. Racisms: From the Crusades to the Twentieth Century. Princeton, NJ: Princeton UP, 2013. Print.

Boxer, Charles R. Women in Iberian Expansion Overseas 1415-1815. Oxford: Oxford UP, 1975. Print.

Bucifferro, Justin R. "A Forced Hand: Natives, Africans, and the Population of Brazil, 1545-1850.” Revista de História Económica 31.2 (2013): 285-317. Print.

Butler, Judith. Precarious Life: The Powers of Mourning and Violence. New York: Verso, 2004. Print.

Coates, Timothy. Convicts and Orphans: Forced and State-Sponsored Colonizers in the Portuguese Empire, 1550-1755. Stanford, CA: Stanford UP, 2001. Print.

Dillon, Michael. "Cared to Death. The Biopoliticised Time of your Life." Foucault Studies 2 (2005): 37-46. Print.

Durantaye, Leland de la. Giorgio Agamben: A Critical Introduction. Stanford, CA: Stanford UP, 2009. Print.

Eisenberg, José. "A escravidão dos índios do Brasil e o pensamento político moderno." Análise Social 39.170 (2004): 7-35. Print.

Foucault, Michel. 'Society Must Be Defended': Lectures at the Collège de France, 1975-76. Ed. Mario Bertani and Alessandro Fontana. Trans. David Macey. New York: Picador, 2003. Print. 
-. The History of Sexuality: An Introduction, Volume I. Trans. Robert Hurley. New York: Vintage, 1990. Print.

Fredrickson, George M. Racism: A Short History. Princeton, NJ: Princeton UP, 2002. Print.

García, Rodolfo. "As órfãs." Revista do Instituto Histórico e Geográfico Brasileiro 192 (1946): 137-42. Print.

Guedes, Ana Isabel Marques. "Tentativas de controle da reprodução da população colonial: as órfas d'el-rei." O rosto feminino da expansão portuguesa. Lisbon: Comissão para a Igualdade e para os Direitos da Mulher, 1995. 665-73. Print.

Hering Torres, Max S. "Purity of Blood. Problems of Interpretation." Race and Blood in the Iberian World. Ed. Max S. Hering Torres, María Elena Martínez, and David Nirenberg. Münster: LIT Verlag, 2012. 11-38. Print.

JanMohamed, Abdul. "Sexuality on/of the Racial Border: Foucault, Wright, and the Articulation of "Racialized Sexuality." Discourses of Sexuality: From Aristotle to AIDS. Ed. Donna Stanton, Ann Arbor, MI: U of Michigan P, 1992. 94-117. Print.

Jaboatão, Antônio de. Catálogo genealógico das pricipaes famílias: que procederam de Albuquerques e Cavalcantes em Pernamubuco e Caramurús na Bahia. Imprensa Oficial, 1950.

Leite, Serafim. Breve itinerário para uma biografia do P. Manuel da Nóbrega, fundador da província do Brasil e da cidade de São Paulo. São Paulo: Brotéria, 1955. Print.

Marcílio, Maria Luiza. "The population of colonial Brazil." The Cambridge History of Latin America, Volume II. Ed. Leslie Bethell. Cambridge: Cambridge UP, 1984. 37-58. Print.

Martínez, María Elena. Genealogical Fictions: Limpieza de Sangre, Religion, and Gender in Colonial Mexico. Stanford, CA: Stanford UP, 2008. Print.

Mattos, Hebe. "'Pretos' and 'Pardos' between the Cross and the Sword: Racial Categories in Seventeenth-Century Brazil." Revista Europea de Estudios Latinoamericanos y del Caribe 80 (2006): 43-55. Print.

McWorther, Ladelle. "Sex, Race, and Biopower: A Foucauldian Genealogy." Hypatia 19.3 (2004): 38-62. Print.

Metcalf, Alida C. Family and Frontier in Colonial Brazil: Santama de Parnaiba 1580-1822. Berkeley, CA: U of California P, 1992. Print. 
Ministério da Educação. Anais da Biblioteca Nacional do Rio de Janeiro, vol. 57. Rio de Janeiro: Ministério da Educação, 1939. Print.

Nagel, Joane. "Ethnicity and Sexuality." Annual Review of Sociology 26 (2000): 107-33. Print.

Nóbrega, Manuel da. Cartas do Brasil e mais escritos do Manuel da Nóbrega (1530-1561). Ed. Serafim Leite. Coimbra: Atlântida, 1955. Print.

- Cartas Jesuíticas I. Belo Horizonte: Itatiaia; São Paulo: U de São Paulo, 1988. Print.

Nirenberg, David. "Race and the Middle Ages. The Case of Spain and Its Jews." Rereading the Black Legend. The Discourses of Religious and Racial Difference in the Renaissance Empires. Ed. Margaret R. Greer, Walter D. Mignolo, and Maureen Quilligan. Chicago: U of Chicago P, 2007. 71-87. Print.

Puga, Rogério Miguel. “'Amansar' o selvage edénico: a retórica do achamento do Brasil na Carta de Pêro Vaz de Caminha.” Romance Studies 30. 2 (2012): 75-84. Print.

Rabinow, Paul, and Nikolas Rose. "Biopower Today" BioSocieties 1 (2006): 195-217. Print.

Rubin, Gayle S. "The Traffic in Women. Notes on the 'Political Economy' of Sex." Deviations: A Gayle Rubin Reader. Durham, NC: Duke UP, 2011. 3365. Print.

Russell-Wood, John R. "Women and Society in Colonial Brazil." Journal of Latin American Studies 9.1 (1977): 1-34. Print.

Schwartz, Stuart B. Early Brazil: A Documentary Collection to 1700. Cambridge: Cambridge UP, 2010. Print.

-. "Indian Labor and New World Plantations: European Demands and Indian Responses in Northeastern Brazil." The American Historical Review 8.1 (1978): 43-79. Print.

—. "Pecar en colonias: Mentalidades populares, inquisición y actitudes hacia la fornicación simple en España, Portugal y las colonias americanas." Cuadernos de Historia Moderna 18 (1997): 51-68. Print.

—. "Sin." Lexikon of the Hispanic Baroque. Ed. Evonne Anita Levy and Kenneth Mills. Austin, TX: U of Texas P, 2013. 321-25. Print. 
Stoler, Ann Laura. Race and the Education of Desire: Foucault's History of Sexuality and the Colonial Order of Things. Durham, NC: Duke UP, 1995. Print.

-. Along the Archival Grain: Epistemic Anxieties and Colonial Common Sense. Princeton, NJ: Princeton UP, 2009. Print.

Sussman, Robert Wald. The Myth of Race: The Troubling Persistence of an Unscientific Idea. Cambridge, MA: Harvard UP, 2014. Print.

Zeron, Carlos Alberto de Moura Ribeiro. Linha de Fé: A Companhia de Jesus e a Escravidão no Processo de Formação da Sociedade Colonial (Brasil, Séculos XVI e XVII). São Paulo: U de São Paulo, 2011. Print. 